\title{
Analisis Ketersediaan dan Kebutuhan Kedelai di Provinsi Sumatera Utara
}

\section{Analysis of Soybean Availability and Needs in North Sumatra Province}

\author{
Sudiwan SItumorang1), Retna Astuti Kuswardani'), Ihsan Effendi ${ }^{3)}$ \\ 1) Magister Agribisnis, Pascasarjana, Universitas Medan Area, Indonesia \\ 2) Dosen Magister Agribisnis, Pascasarjana, Universitas Medan Area, Indonesia \\ 3) Dosen Magister Agribisnis, Pascasarjana, Universitas Medan Area, Indonesia
}

\begin{abstract}
Abstrak
Ketersediaan kedelai di Propinsi Sumatera Utara harus benar benar diperhatikan, hal ini diakibatkan karena kedelai merupakan pangan ketiga terpenting setelah padi dan jagung. Penelitian ini bertujuan untuk menganalisis faktor-faktor yang mempengaruhi ketersediaan dan kebutuhan kedelai di Sumatera Utara. Penelitian ini menggunakan data sekunder tentang ketersediaan dan kebutuhan kedelai di Sumatera Utara dari tahun 20082017. Data sekunder yang dikumpulkan dalam penelitian ini berasal dari instans-iinstansi terkait seperti Badan Pusat Statistik, Badan Ketahanan Pangan Provinsi Sumatera Utara, Dinas Pertanian Provinsi Sumatera Utara dan Balai Besar Karantina Pertanian Belawan. Dari penelitian ini didapatkan bahwa ketersediaan kedelai di Sumatera Utara dipengaruhi oleh luas panen, produksi kedelai dan impor kedelai. Kebutuhan kedelai di Sumatera Utara dipengaruhi oleh jumlah penduduk, konsumsi/perkapita dan ketersedian kedelai. Analisis ketersediaan dan kebutuhan kedelai di Sumatera Utara mengalami fluktuasi di tahun 2008-2017.

Kata Kunci: Ketersediaan, Kebutuhan, Kedelai, impor kedelai
\end{abstract}

\section{Abstract}

Soybean availability in North Sumatra Province have to be considered, this is caused by soybean being the third most important food after rice and corn. This study aims to analyze the factors that influence the availability and needs of soybeans in North Sumatra. This study uses secondary data on the availability and needs of soybeans in North Sumatra from 2008-2017. Secondary data collected in this study came from related agencies such as the Central Statistics Agency, the North Sumatra Province Food Security Agency, the North Sumatra Province Agriculture Office and the Belawan Agricultural Quarantine Center. From this study it was found that the availability of soybeans in North Sumatra was influenced by harvested area, soybean production and soybean imports. Soybean needs in North Sumatra are influenced by population, consumption / per capita and soybean availability. Analysis of soybean availability and needs in North Sumatra experienced fluctuations in 2008-2017.

Keywords: Availability is influenced by soybean harvest area, soybean production and soybean import and soybean needs influenced by population, consumption / capita and soybean availability

How to Cite: Situmorang, S. R. A. Kuswardani \& I. Effendi. Analisis Ketersediaan dan Kebutuhan Kedelai di Provinsi Sumatera Utara. (2020). Jurnal Ilmiah Magister Agribisnis, 2(2) 2020: 194-207,

*E-mail: retnaastuti@uma.ac.id ISSN 2550-1305 (Online)

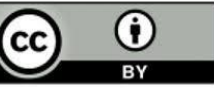




\section{PENDAHULUAN}

Dalam Undang-Undang No.18 Tahun 2012 tentang Pangan, Ketahanan Pangan didefenisikan sebagai kondisi terpenuhinya pangan bagi Negara sampai dengan perseorangan, yang tercermin dari tersedianya pangan yang cukup, baik jumlah maupun mutunya, aman, beragam, bergizi, merata dan terjangkau serta tidak bertentangan dengan agama, keyakinan, dan budaya masyarakat, untuk dapat hidup sehat, aktif dan produktif secara berkelanjutan. Tiga pilar dalam ketahanan pangan yang terdapat dalam defenisi tersebut adalah ketersediaan (availability), keterjangkauan (accessibility) baik secara fisik maupun ekonomi, dan stabilitas (stability) yang harus tersedia dan terjangkau setiap saat dan setiap tempat. Dalam membangun ketahanan pangan nasional sebuah negara, ketiga pilar ketahanan pangan tersebut saling terkait satu sama lain. Apabila ketiga pilar ketahanan pangan terpenuhi, maka masyarakat atau rumah tangga mampu memenuhi ketahanan pangannya masing-masing (BKP Kementan, 2011).

Tanaman pangan merupakan salah satu komoditas terpenting yang menunjang ketahanan pangan nasional, karena pangan merupakan salah satu kebutuhan pokok masyarakat yang pemenuhannya menjadi hak masyarakat Indonesia, dan salah satu komoditas tanaman pangan yang paling penting dikonsumsi adalah kedelai. Kedelai merupakan komoditas strategis yang unik di dalam sistem usaha tani Indonesia. Kedelai termasuk dalam tiga besar komoditas pangan utama di Indonesia selain padi dan jagung. Peran kedelai sangat penting terhadap perkembangan penduduk Indonesia. (Supadi, 2009).

Kedelai di Indonesia lebih banyak digunakan sebagai bahan baku industri olahan dan sisanya untuk pakan ternak serta benih. Kedelai dapat diolah menjadi tempe, tahu, kecap, tauco, dan susu kedelai. Produk-produk olahan kedelai tersebut merupakan menu penting dalam pola konsumsi sebagian besar masyarakat Indonesia, terutama masyarakat di Pulau Jawa. Hal tersebut menjadikan kedelai sebagai salah satu komoditas penting di Indonesia (Ginting at al., 2009).

Kebutuhan terhadap kedelai di Indonesia setiap tahun mengalami peningkatan. Tercatat kebutuhan kedelai tahun 2012 sebesar 2,2 juta ton dibandingkan dengan kebutuhan tahun 2011 sebesar 2,16 juta ton. Dari kebutuhan tersebut rata-rata yang mampu dipenuhi oleh produksi dalam negeri sekitar 25-30 persen dimana sisanya diperoleh dari berbagai negara melalui mekanisme impor. Berdasarkan data Badan Pusat Statistik (BPS), tahun 2011 produksi kedelai lokal hanya sebesar 851.286 ton atau $29 \%$ dari total kebutuhan, sehingga Indonesia harus melakukan impor kedelai sebanyak 2.087.986 ton untuk memenuhi 71\% kebutuhan kedelai dalam negeri (Nanang, 2012).

Rendahnya produksi kedelai di di Sumatera Utara antara lain disebabkan masih rendahnya produktivitas di tingkat petani, rata-rata hanya mencapai 13,78 kwintal/ha pada tahun 2011, sedangkan potensi produksi beberapa varietas unggul dapat mencapai 20,00-35,00 kwintal/ha, hal ini karena belum diterapkannya teknologi spesifik lokasi, selain itu harga kedelai di tingkat petani yang berfluktuatif dan cenderung rendah merupakan penyebab utama berkurangnya minat petani menanam kedelai (Deptan, 2012).

Faktor harga juga turut berpengaruh terhadap ketersediaan kedelai dimana harga kedelai impor kini mencapai Rp 8.200 per kg atau naik 49\% dibandingkan awal tahun ini Rp 5.500 per kg. Perajin tahu dan tempe mengkhawatirkan harga itu diprediksi bisa menembus Rp 10.000 per kg. Akibatnya para perajin tahu dan tempe mengeluh karena harga tahu dan tempe yang melambung tinggi. Biaya produksi yang signifikan mengakibatkan mereka tidak berani menaikkan harga jual dan tidak sedikit perajin yang harus bersedia mengurangi keuntungannya hingga 30\% bahkan berhenti berproduksi. 
Tinggi rendahnya harga kedelai di pasar domestik sangat bergantung pada mekanisme pasar (Samhadi, 2008).

Volume impor adalah faktor lain yang mempengaruhi tingkat ketersediaan kedelai di Sumatera Utara, karena ketergantungan impor di Sumatera Utara yang sangat tinggi maka gejolak harga internasional sangat rentan sekali terhadap pasokan di di Sumatera Utara. Kondisi ini juga berpengaruh terhadap pasar domestik, untuk mendapatkan kedelai lokal sudah tidak ada lagi, hal ini dikarenakan seluruh kedelai yang ada di eceran kebanyakan kedelai impor dari Amerika Serikat. Hal ini berbanding terbalik karena Indonesia yang merupakan negara penghasil kedelai, tetapi melakukan impor kedelai dalam jumlah yang tidak sedikit. Dan pada akhirnya menimbulkan asumsi dari masyarakat bahwa impor kedelai dipicu oleh produksi kedelai di Sumatera Utara yang tidak mencukupi. Dalam hal ini pemerintah diharapkan melakukan pengendalian harga eceran kedelai (Samhadi, 2008).

Dengan mempertimbangkan permasalahan pangan tersebut di atas maka perlu dikaji Analisis Ketersediaan dan Kebutuhan Kedelai di Provinsi Sumatera Utara berdasarkan data sepuluh tahun terakhir untuk memberikan gambaran ketersediaan dan kebutuhan kedelai selama 10 Tahun terakhir dan faktor-faktor yang mempengaruhi ketersediaan dan kebutuhan kedelai di Provinsi Sumatera Utara. Hasil analisis ini sangat penting untuk menentukan program/kegiatan yang berkaitan dengan ketahanan pangan, khususnya kedelai di Sumatera Utara ke depan.

\section{METODE PENELITIAN}

Penelitian ini dilakukan di Provinsi Sumatera Utara. Waktu penelitian dilaksanakan selama 3 (tiga) bulan dimulai Bulan Pebruari s/d Bulan April 2019. Bentuk penelitian ini adalah penelitian deskriptif yang bermaksud untuk membuat deskripsi ketersediaan dan kebutuhan kedelai di Sumatera Utara. Analisis yang digunakan yaitu analisis deskriptif studi literatur dan analisis kuantitatif untuk data sekunder yang didapatkan dengan cara mencari dokumen-dokumen pendukung atau laporan dari dinas/instansi terkait yaitu Dinas Ketahanan Pangan dan Peternakan Provinsi Sumatera Utara, Badan Pusat Statistik Provinsi Sumatera Utara dan Balai Besar Karantina Pertanian Belawan.

Penelitian ini menggunakan data sekunder dari 33 Kabupaten/Kota di Provinsi Sumatera Utara. Data diambil selama 10 tahun yaitu mulai tahun 2008 sampai tahun 2017. Data bersumber dari Badan Pusat Statistik Provinsi Sumatera Utara, Dinas Ketahanan Pangan Peternakan Provinsi Sumatera Utara, dan Balai Besar Karantina Pertanian Belawan serta dilengkapi dengan studi kepustakaan. Provinsi Sumatera Utara dipilih secara purposive (sengaja) dengan mempertimbangkan bahwa daerah ini merupakan daerah yang layak untuk diketahui ketersediaan dan kebutuhan Kedelai .Penelitian ini menggunakan analisis deskriptif untuk menganalisis ketersediaan dan kebutuhan kedelai kurun waktu sepuluh tahun terakhir (2008-2017) di provinsi Sumatera Utara.

\section{HASIL DAN PEMBAHASAN}

Ketersediaan kedelai adalah jumlah produksi bersih kedelai ditambah impor kedelai yang terdapat di Provinsi Sumatera Utara dalam jangka satu tahun setelah dikurangi Kebutuhan pakan, bibit, tercecer dan kebutuhan industri, satuan jumlah ketersediaan kedelai adalah ton/tahun. Ketersediaan bahan pangan strategis dalam hal ini kedelai di Provinsi Sumatera Utara kurun waktu 10 (sepuluh) dapat kita lihat seperti tabel 1. 
Tabel 1. Ketersediaan kedelai di Provinsi Sumatera Utara Tahun 2008-2017 sebelum Impor

\begin{tabular}{lllllll}
\hline \hline Tahun & $\begin{array}{l}\text { Produksi } \\
\text { Kedelai } \\
\text { (Ton) }\end{array}$ & $\begin{array}{l}\text { Tercecer } \\
5 \%\end{array}$ & $\begin{array}{l}\text { Pakan } \\
\text { Ternak } \\
0,34 \%\end{array}$ & $\begin{array}{l}\text { Benih } \\
50 \mathrm{~kg} / \mathrm{Ha} \\
\text { X l. tanam }\end{array}$ & $\begin{array}{l}\text { Keb. } \\
\text { Industri } \\
(2,76 \\
\mathrm{kg} / \mathrm{kap} / \mathrm{thn}\end{array}$ & $\begin{array}{l}\text { Ketersediaan } \\
\text { kedelai }\end{array}$ \\
\hline 2008 & 11.648 & 582,40 & 39,6 & 502,6 & $34.952,1$ & $(24.426)$ \\
2009 & 14.206 & 710,30 & 48,3 & 691,8 & $36.565,5$ & $(23.809)$ \\
2010 & 9.438 & 471,89 & 32,1 & 385,3 & $36.626,6$ & $(28.078)$ \\
2011 & 11.425 & 571,26 & 38,9 & 745,8 & $35.830,9$ & $(25.761)$ \\
2012 & 5.419 & 270,95 & 18,4 & 272,5 & $36.474,5$ & $(31.616)$ \\
2013 & 3.229 & 161,46 & 10,9 & 208,8 & $36.780,6$ & $(33.933)$ \\
2014 & 5.705 & 285,25 & 19,4 & 250,2 & $37.996,5$ & $(32.844)$ \\
2015 & 6.549 & 327,46 & 22,7 & 390,6 & $38.473,8$ & $(32.665)$ \\
2016 & 5.062 & 253 & 17,2 & 369,9 & 38.924 & $(34.504)$ \\
2017 & 7.768 & 388,32 & 26,4 & 239,9 & 38.924 & $(31.812)$
\end{tabular}

Sumber : Data Sekunder (diolah), 2017

Dari Tabel 1 dapat diketahui bahwa kondisi ketersediaan kedelai di propinsi Sumatera Utara cenderung menurun dan tidak mampu untuk memenuhi kebutuhan penduduk di Sumatera Utara. Faktor-faktor yang mempengaruhi ketersediaan kedelai dipropinsi Sumatera Utara antara lain Luas Panen dan Perkembangan jumlah Penduduk terhadap kebutuhan Kedelai.

\section{Analisis Luas Panen kedelai terhadap ketersediaan kedelai di Provinsi Sumatera Utara}

Berdasarkan data 10 Tahun terakhir Tahun 2008-2017 diketahui luas panen kedelai di Sumatera Utara pada table 2. Berdasarkan data tersebut diatas dapat di lihat bahwa luas panen kedelai di Sumatera Utara cenderung fluktuatif dan menurun dengan persamaan $y=-721,92 x+10890$. Luas panen paling tinggi adalah pada tahun 2009 yaitu 11.494 Ha mengakibatkan ketersedian kedelai minus (23.809), sementara luasan panen paling sedikit adalah pada tahun 2013 yaitu 3.126 Ha mengakibatkan ketersedian kedelai minus (33.933). Pertumbuhan rata-rata luas panen selama 10 tahun terakhir adalah $3.17 \%$ dengan pertumbuhan negatif pada beberapa tahun. Pertumbuhan yang negatif terjadi akibat penurunan luasan panen dibandingkan tahun sebelumnya. Hal ini terlihat dari garis linier pada grafik tersebut di atas dan persamaan yang menyertainya. Hal ini perlu mendapat perhatian khusus dari seluruh pihak terkait. Penambahan luasan panen kedelai perlu ditingkatan untuk dapat memenuhi kebutuhan masyarakat Sumatera Utara.

Tabel 2. Luas Panen Kedelai terhadap ketersediaan kedelai di Sumatera Utara

\begin{tabular}{cccc}
\hline Tahun & Luas Panen Kedelai $(\mathrm{Ha})$ & Produksi & Ketersediaan \\
\hline $\mathbf{2 0 0 8}$ & 9.597 & 11.648 & $(24.426)$ \\
$\mathbf{2 0 0 9}$ & 11.494 & 14.206 & $(23.809)$ \\
$\mathbf{2 0 1 0}$ & 7.803 & 9.438 & $(28.078)$ \\
$\mathbf{2 0 1 1}$ & 11.413 & 11.425 & $(25.761)$ \\
$\mathbf{2 0 1 2}$ & 5.475 & 5.419 & $(31.616)$ \\
$\mathbf{2 0 1 3}$ & 3.126 & 3.229 & $(33.933)$ \\
\hline
\end{tabular}




\begin{tabular}{llll}
\hline $\mathbf{2 0 1 4}$ & 5.024 & 5.705 & $(32.844)$ \\
$\mathbf{2 0 1 5}$ & 5.303 & 6.549 & $(32.665)$ \\
$\mathbf{2 0 1 6}$ & 3.955 & 5.062 & $(34.504)$ \\
$\mathbf{2 0 1 7}$ & 6.005 & 7.768 & $(31.812)$ \\
\hline
\end{tabular}

Sumber : Badan Pusat Statistik Sumatera Utara, data diolah (2017)

Untuk memenuhi ketersediaan kedelai di propinsi Sumatera Utara pada tahun 2017 sebesar 39.580 ton dengan tingkat produktifitas kedelai yang rata rata 1,33 ton/ha maka dibutuhkan luas panen seluas 29.759, 4 ha. Luas panen ini sulit terpenuhi karena beberapa faktor antara lain struktur biaya produksi kedelai lebih besar dibandingkan nilai produksi yang dihasilkan dari setiap hektar lahan kedelai.

Menurut data Badan Pusat statistik, biaya produksi tanam kedelai sebesar Rp 9,1 juta/hektar/musim sedangkan petani hanya mampu meraup hasil produksi kedelai sebesar Rp 9 juta/hektar/musim. Sementara itu sesuai data BPS, untuk komoditas tanaman pangan lain seperti padi sawah nilai produksinya 17,2 juta sedangkan biaya produksinya adalah 12,7 juta, terdapat keuntungan sebesar 4,5 juta dan jagung nilai produksinya adalah 12 juta dan biaya produksinya adalah 9,1 juta terdapat keuntungan sebesar 2,9 juta rupiah, sedangkan kedelai mengalami kerugian sebesar 100 ribu Rupiah. Akibat dari kerugian tersebut maka petani akan malas menanam kedelai dan akan cenderung menanam padi dan jagung yang jelas-jelas memberikan keutungan.

\section{Harga Kedelai}

Faktor lain juga yang mempengaruhi menurunnya luas panen kedelai adalah faktor harga kedelai. Persoalan harga kedelai menjadi pekerjaan pemerintah untuk mendorong petani kedelai agar kembali menanam. Selama ini pada saat panen harga kedelai selalu jatuh dan tidak ada pasar yang menampung, sehingga petani lebih memilih untuk menanam padi atau jagung yang lebih menguntungkan. Harga kedelai sepenuhnya ditentukan oleh mekanisme pasar, yang tergantung pada permintaan dan penawaran (demand and supply). (Damardjati et al. 2005).

Tabel 3. Harga Kedelai lokal dan impor di Sumatera Utara Tahun 2008-2017

\begin{tabular}{clc}
\hline Tahun & $\begin{array}{l}\text { Harga Kedelai } \\
\text { lokal }\end{array}$ & $\begin{array}{c}\text { Harga kedelai } \\
\text { impor (US } \$ \text { MT) }\end{array}$ \\
\hline 2008 & 7.046 & 522,8333 \\
2009 & 6.208 & 436,9167 \\
2010 & 6.000 & 449,7958 \\
2011 & 6.448 & 540,6667 \\
2012 & 6.500 & 591,4167 \\
2013 & 8.286 & 538,4167 \\
2014 & 9.000 & 491,7708 \\
2015 & 8.850 & 390,4167 \\
2016 & 7.500 & 405,6667 \\
2017 & 8.500 & 449,66557 \\
\hline
\end{tabular}

Sumber : Badan Pusat Statistik,Di Olah Tahun 2017

Database Global Economic Monitor Commodities (Worldbank), 2017

Dilihat dari tabel 3 maka dapat disimpulkan bahwa harga kedelai impor jauh lebih murah dibandingkan harga kedelai lokal. Hal ini mengakibatkan kedelai impor akan lebih diminati oleh masyarakat Sumatera Utara karena lebih menguntungkan. Dilihat dari data 
yang ada untuk tahun 2017 harga kedelai local sebesar Rp. 8.500,- sedangkan harga kedelai impor dengan asumsi harga 1 dolar sebesar Rp. 14.000,- maka harga kedelai impor untuk 1 kg hanya Rp. 6.295,-- sehingga terjadi selisih harga sebesar Rp. 2.205,-. Hal ini merupakan disinsentif bagi petani dalam menanam kedelai. Selama harga kedelai impor lebih rendah, maka arus impor akan makin deras, sehingga harga kedelai produksi dalam negeri akan makin turun. Hal ini menyebabkan petani enggan menanam kedelai. Jika kondisi ini terus berlangsung tanpa ada terobosan kebijakan dalam pemasaran kedelai, maka prospek pengembangan kedelai di Indonesia akan makin buruk (Damardjati et al. 2005).

Damardjati et al. (2005) mengungkapkan bahwa penurunan harga riil kedelai diduga menjadi disinsentif yang menyebabkan terjadinya penurunan areal panen Kedelai. Selain itu, persaingan penggunaan lahan dengan palawija lainnya juga merupakan salah satu penyebab turunnya areal panen kedelai. Indikatornya ialah kenaikan harga riil jagung. Secara teoritis, kenaikan harga akan mendorong petani untuk menanam komoditas tersebut. Konsekuensinya ialah kenaikan areal tanam jagung (sebagai komoditas pesaing) dengan sendirinya akan mengurangi areal untuk Kedelai, karena lahan yang digunakan adalah lahan yang sama.

Untuk meningkatkan areal luas panen di propinsi Sumatera Utara, Kementerian pertanian Republik Pemerintah telah melakukan terobosan dengan Mencanangkan kembali upaya khusus (UPSUS PAJALE) pada tahun 2015.

Adanya Upaya penambahan luas tambah tanam khusus padi, jagung dan kedelai telah menambah luas areal panen pada Tahun 2017 menjadi 6.005 Ha. Untuk mencapai peningkatan luas panen tersebut pemerintah menyiapkan alokasi anggaran bantuan untuk Kegiatan Pengelolaan Produksi Kedelai melalui APBN-P Tahun 2017 senilai Rp. 45.786.500.000,- dengan rincian untuk bantuan sarana produksi (benih, urea subsidi, rhizobium, dolomit dan pestisida) sebesar Rp. 44.131.500.000,- dan untuk biaya pengawalan, monitoring, evaluasi tingkat pusat dan daerah adalah sebesar Rp. 1.655.000.000,- (Kementrian Pertanian, 2017). Pada Tahun 2018 luas tambah tanam berdasarkan data yg masuk telah meningkat menjadi 29.858,6 Ha. Dengan luas panen sebesar $25.850 \mathrm{Ha}$ dengan produksi sebesar 32.623 Ton, berdasarkan laporan SPPALAWIJA dari Dinas Pertanian Kabupaten/Kota, diolah dengan SIM-TP BPS.

Analisis Produksi kedelai terhadap ketersediaan kedelai di Provinsi Sumatera Utara

Perkembangan produksi kedelai selama kurun waktu 10 (sepuluh) tahun terakhir mulai tahun 2008-2017 di Provinsi Sumatera Utara dapat dilihat pada Gambar 1.

Berdasarkan data tersebut diatas dapat di lihat bahwa produksi kedelai di Sumatera Utara cenderung fluktuatif dan menurun dengan persamaan $\mathrm{y}=-803,84 \mathrm{x}+$ 12467. Jika tidak ada upaya perbaikan terhadap perbaikan produksi kedelai maka produksi kedelai akan terus menurun dan akan mendekati titik nol artinya produksi kedelai tidak ada lagi. Pertumbuhan rata-rata produksi kedelai selama 10 tahun terakhir adalah 4,09 \% dimana pertumbuhan tersebut ada yang negatif pada beberapa Tahun yaitu Tahun 2010,2012, 2013, dan 2016 dibandingkan dengan tahun sebelumnya. Hal ini perlu mendapat perhatian khusus dari seluruh pihak terkait. Penambahan produksi kedelai perlu ditingkatan untuk dapat memenuhi kebutuhan masyarakat Sumatera Utara. Untuk memenuhi ketersediaan kedelai di propinsi Sumatera Utara pada tahun 2017 maka dibutuhkan produksi kedelai sebesar 39.580 Ton. 
Sudiwan Situmorang, Retna Astuti Kuswardani \& Ihsan Effendi. Analisis Ketersediaan dan Kebutuhan Kedelai di Provinsi Sumatera Utara.

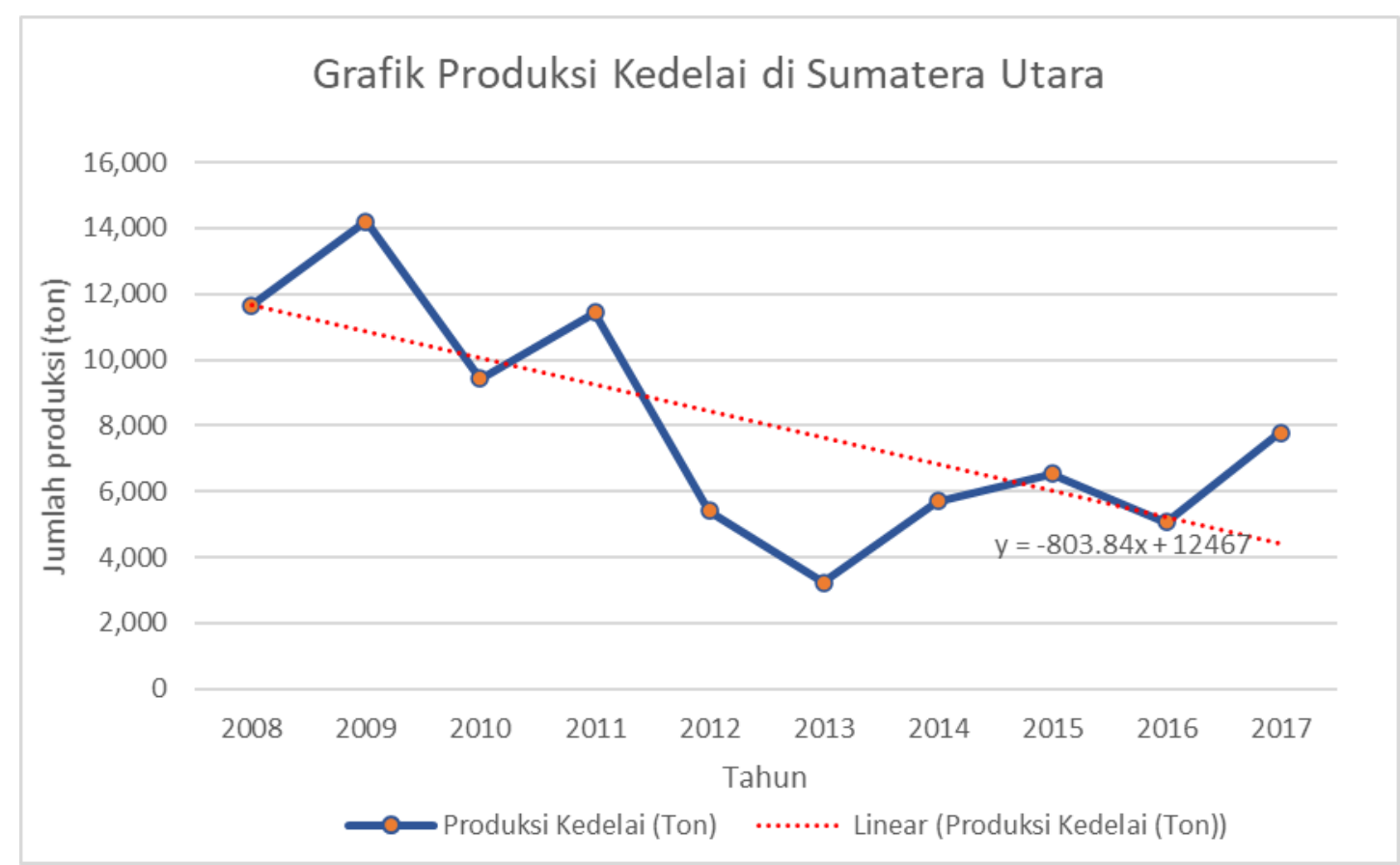

Gambar 1. Grafik Produksi Kedelai Di Sumatera Utara

Produksi kedelai ini sulit terpenuhi di propinsi Sumatera Utara karena beberapa faktor antara lain:

\section{Rendahnya produktifitas}

Rendahnya produksi kedelai diSumatera Utara untuk periode 2008-2017 diakibatkan rendahnya Produktivitas atau kemampuan produksi setiap hektar lahan atau areal Panen. Rumus produktivitas lahan adalah sebagai berikut:

$$
P(\text { produktivity })=\frac{\text { Jumlah produksi }}{\text { Luasan panen }}
$$

Jumlah panen $=$ Jumlah produksi dalam setahun produksi (Ton)

Luasan panen = Luasan lahan yang dipanen dalam setahun

(ha)

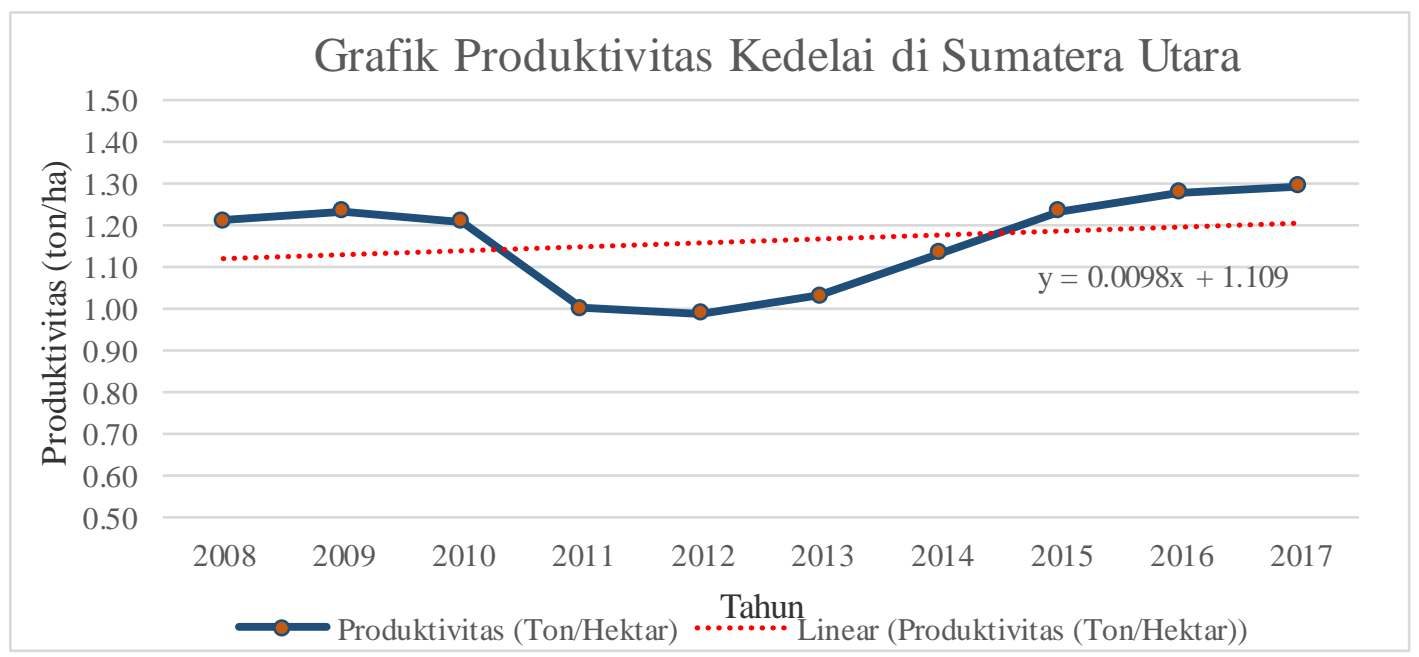


Gambar 2. Produktifitas Kedelai di Sumatera Utara Tahun 2008-2017

Pada data hasil produksi kedelai yang tersedia maka dapat disimpulkan bahwa rata rata produktifitas selama 10 tahun adalah 1,16 ton per Ha. Hasil produksi tertinggi terjadi pada tahun 2009 sebanyak 14.206 Ton dari luas panen 11.494 Ha dan produktivitas 1,14 Ton/ Ha. Hasil produksi terendah terjadi pada tahun 2013 sebanyak 3.229 Ton dari luas panen 3.126 Ha dengan produktifitas 1,03 Ton/ Ha.

Berdasarkan grafik diatas dapat dilihat bahwa produktivitas kedelai di Sumatera Utara untuk periode 2008-2017 cenderung stabil. Produktivitas dapat ditingkatkan melalui introduksi inovasi teknologi. Salah satu komponen teknologi yang paling mudah dan cepat menyebar adalah varietas unggul baru (VUB) yang berdaya hasil tinggi, karena kontribusi varietas unggul dalam meningkatkan produktivitas paling mudah dilihat dan dipahami oleh petani. Oleh karena itu, perakitan varietas unggul baru yang mempunyai karakter produktivitas tinggi serta toleran terhadap cekaman lingkungan biotik dan abiotik sangat diperlukan dalam rangka peningkatan produksi Kedelai. Saat ini ada beberapa varietas unggul Kedelai yang telah dilepas ke masyarakat (Samhadi, 2008).

\section{Jenis Varietas Unggul kedelai yang ditanam}

Varietas Kedelai unggulan yang di tanam di Sumatera Utara antara lain adalah Sinabung, Burangrang, Anjasmoro, Argomulyo. Varietas unggul baru yang dilepas ini mempunyai potensi hasil rata-rata 2,5 t/ha. Namun di tingkat petani di Sumatera Utara potensi hasil yang dicerminkan oleh rataan produktivitas baru mencapai 1,16 t/ha untuk 10 Tahun terakhir mulai dari Tahun 2008 sampai dengan Tahun 2017. Ini berarti bahwa masih terdapat potensi dan peluang yang sangat besar untuk meningkatkan produksi Kedelai melalui peningkatan produktivitas. Yang menjadi masalah hingga kini adalah baru $10 \%$ petani yang menggunakan varietas unggul yang berlabel. Oleh karena itu perlu dianjurkan kepada petani agar menanam bibit yang unggul dan berlabel.

Upaya sosialisasi penggunaan varietas unggul sangat diperlukan untuk meningkatkan produksi Kedelai melalui peningkatan produktivitas. Selain varietas unggul, komponen teknologi lainnya yang disinergikan dengan varietas unggul adalah pengelolaan LATO (lahan, air, tanaman, dan organisme pengganggu). Inovasi teknologi dengan penggunaan benih bermutu, pembuatan saluran drainase, pemberian air yang cukup, pengendalian hama dan penyakit dengan sistem pengendalian hama terpadu (PHT), panen dan pascapanen dengan alsintan diharapkan mampu meningkatkan produksi Kedelai mendekati potensi genetiknya. Teknologi produksi yang dikemas dalam Pengelolaan Tanaman Terpadu (PTT) pada tanaman Kedelai diharapkan mampu meningkatkan produksi hingga 2 ton/ha.

\section{Analisis Total volume Impor kedelai terhadap ketersediaan kedelai di Provinsi Sumatera Utara}

Perkembangan impor kedelai selama kurun waktu 10 (sepuluh) tahun terakhir mulai tahun 2008-2017 di Provinsi Sumatera Utara dapat kita lihat seperti tabel dibawah ini.

Berdasarkan data tersebut diatas dapat di lihat bahwa jumlah volume impor kedelai di Sumatera Utara cenderung fluktuatif dan terus naik. Hal ini dapat kita lihat dari persamaan linier selama 10 tahun terakhir yaitu $\mathrm{y}=14541 \mathrm{x}+41288$. Jumlah volume impor yang paling tinggi terjadi pada tahun 2017 yaitu sebesar 217.179 ton mengakibatkan ketersedian kedelai surpulus sebesar 184.630 ton, sementara jumlah volume impor yang paling rendah adalah pada tahun 2008 yaitu 65.449 ton yang mengakibatkan jumlah ketersedian kedelai surplus sebeasr 40.797,8 ton. Pertumbuhan rata-rata volume impor selama 10 tahun terakhir adalah 10,88 \% dengan pertumbuhan positip pada sepanjang tahun. Pertumbuhan volume impor ini terjadi akibat kurangnya 
penurunan luasan panen dan produksi di Sumatera Utara Hal ini perlu mendapat perhatian khusus dari seluruh pihak terkait. Jika volume impor terus naik maka ketahanan pangan kita terhadap kebutuhan kacang impor akan tergantung kepada Negara lain dan ini tidak baik terhadap ketahanan pangan nasional.

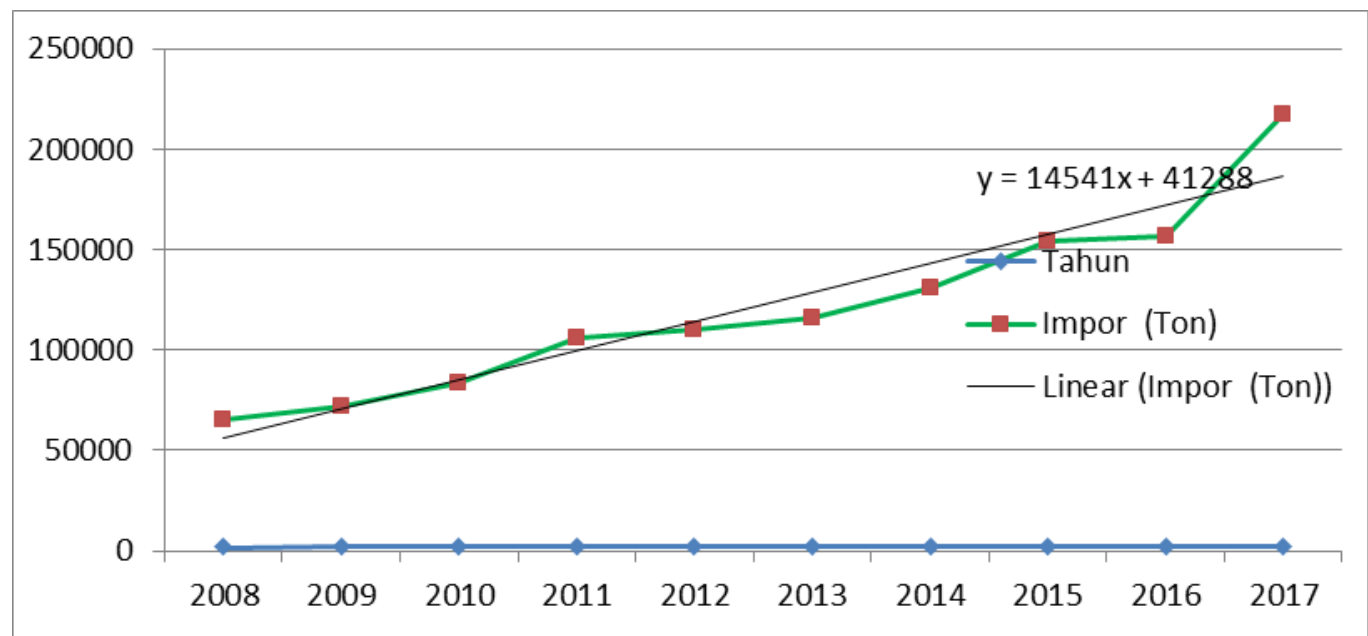

Gambar 3. Grafik Total Volume Impor Kedelai di Suamtera Utara

Perusahaan yang melakukan Impor di provinsi Sumatera Utara melalui Balai Besar Karantina Pertanian Belawan adalah PT.Mabar Feed Indonesia, PT. Agri Tunas Makmur, PT.Agrico International, PT. Cargil Trading Indonesia, PT. Charon Pokphand Indonesia, PT.FKS Multi Agro TBK, PT.Maxmaster Indonesia, PT.Sabas Indonesia, PT.Jakson Niagatama, PT.Koda Putra Indo, PT. Mabar Mitra Bersama. Perusahaan-perusahan tersebut bergerak di berbagai bidang antara lain, pangan, pakan ternak, distributor bahan baku industri kedelai.

Dengan adanya impor kedelai ke Sumatera Utara maka ketersediaan kedelai di Sumatera Utara mengalami surplus. Surplus kedelai yang terjadi digunakan untuk memenuhi kebutuhan propinsi lain seperti Padang dan Aceh. Surplus juga digunakan sebagai bahan pakan ternak pengganti jagung karena larangan impor jagung untuk pakan ternak pada Tahun 2015.

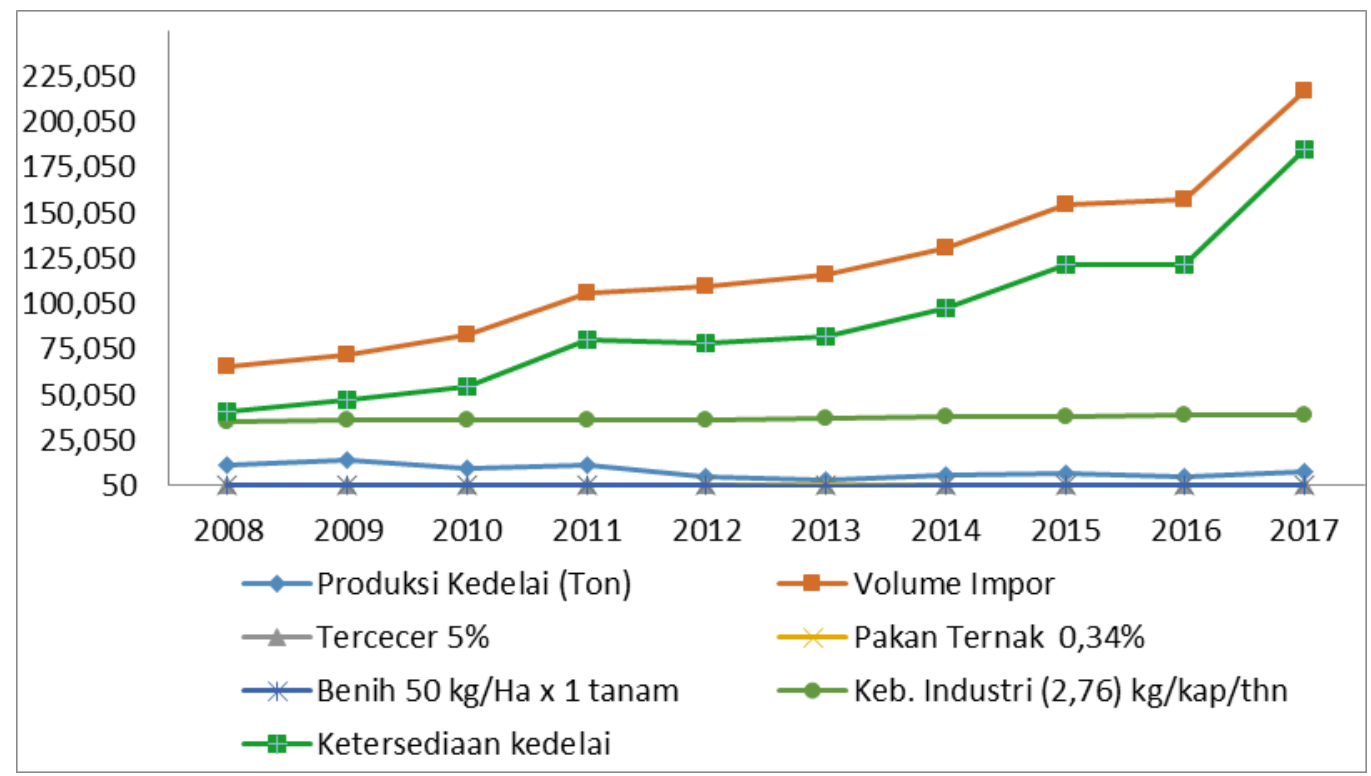


Gambar 4. Grafik ketersedian kedelai setelah Impor dan peruntukannya

Untuk Tahun 2017 biaya yang harus di keluarkan pemerintah (perusahaan) untuk meng impor kedelai tersebut adalah sebesar Rp.763.390.369,560,- dengan biaya $6.295,38 / \mathrm{Kg}$. Berdasarkan persaingan harga pasar, ternyata harga riil kedelai impor jauh lebih murah dari pada kedelai produksi dalam negeri.

Kondisi kebutuhan Kedelai di Sumatera Utara tahun 2008 - 2017

Kebutuhan kedelai adalah jumlah kedelai yang dibutuhkan manusia untuk mempertahankan hidup serta untuk memperoleh kesejahteraan dan kenyamanan. Salah satu faktor lain yang perlu diketahui untuk menganalisa cukup atau tidaknya ketersediaan kedelai di Sumatera Utara adalah kebutuhan. Kebutuhan kedelai tersebut dapat dilihat pada tabel berikut ini.

Tabel 11. Kebutuhan kedelai di Provinsi Sumatera Utara

\begin{tabular}{lll}
\hline \hline Tahun & $\begin{array}{c}\text { Total } \\
\text { Kebutuhan (Ton) }\end{array}$ & Pertumbuhan (\%) \\
\hline \hline $\mathbf{2 0 0 8}$ & $74.258,2$ & - \\
\hline $\mathbf{2 0 0 9}$ & $78.269,6$ & 5,1 \\
\hline $\mathbf{2 0 1 0}$ & $77.757,7$ & $-0,7$ \\
\hline $\mathbf{2 0 1 1}$ & 77.274 & $-0,7$ \\
\hline $\mathbf{2 0 1 2}$ & $77.849,8$ & 0,7 \\
\hline $\mathbf{2 0 1 3}$ & $82.599,7$ & 5,8 \\
\hline $\mathbf{2 0 1 4}$ & 95.854 & 13,8 \\
\hline $\mathbf{2 0 1 5}$ & 97.868 & 1,9 \\
\hline $\mathbf{2 0 1 6}$ & $111.458,8$ & 12,2 \\
\hline $\mathbf{2 0 1 7}$ & 137.157 & 18,7 \\
\hline \hline Rata -rata & $91.034,7$ & $\mathbf{5 , 7}$ \\
\hline \hline
\end{tabular}

Sumber : Data Primer (diolah), 2017

Berdasarkan tabel tersebut di atas dapat disimpulkan bahwa pada tahun 2008 kebutuhan Kedelai Provinsi Sumatera Utara sebesar 74.258,2 ton naik menjadi 137.157 ton pada tahun 2017. Kebutuhan tersebut diperuntukkan untuk memenuhi pakan ternak 0,34 persen, tercecer 5 persen dari hasil produksi, benih $50 \mathrm{~kg} / \mathrm{Ha}$ untuk satu kali penanaman, kebutuhan industri sebanyak 2,76/ kapita/Tahun dan konsumsi langsung (kebutuhan rumah tangga yang selalu berubah ubah setiap tahun) yang cenderung naik dimana tahun 2008 sebesar 3,06 Kg/Kapita/Tahun naik menjadi 6,79 Kg/Kapita/tahun pada Tahun 2017. Faktor-faktor yang mempengaruhi kebutuhan kedelai dipropinsi Sumatera Utara antara lain:

Analisis Perkembangan jumlah Penduduk terhadap kebutuhan Kedelai di Provinsi Sumatera Utara Tahun 2008 - 2017

Perkembangan Jumlah Penduduk selama kurun waktu 10 (sepuluh) tahun terakhir mulai tahun 2008-2017 di Provinsi Sumatera Utara dapat dilihat pada tabel berikut. 


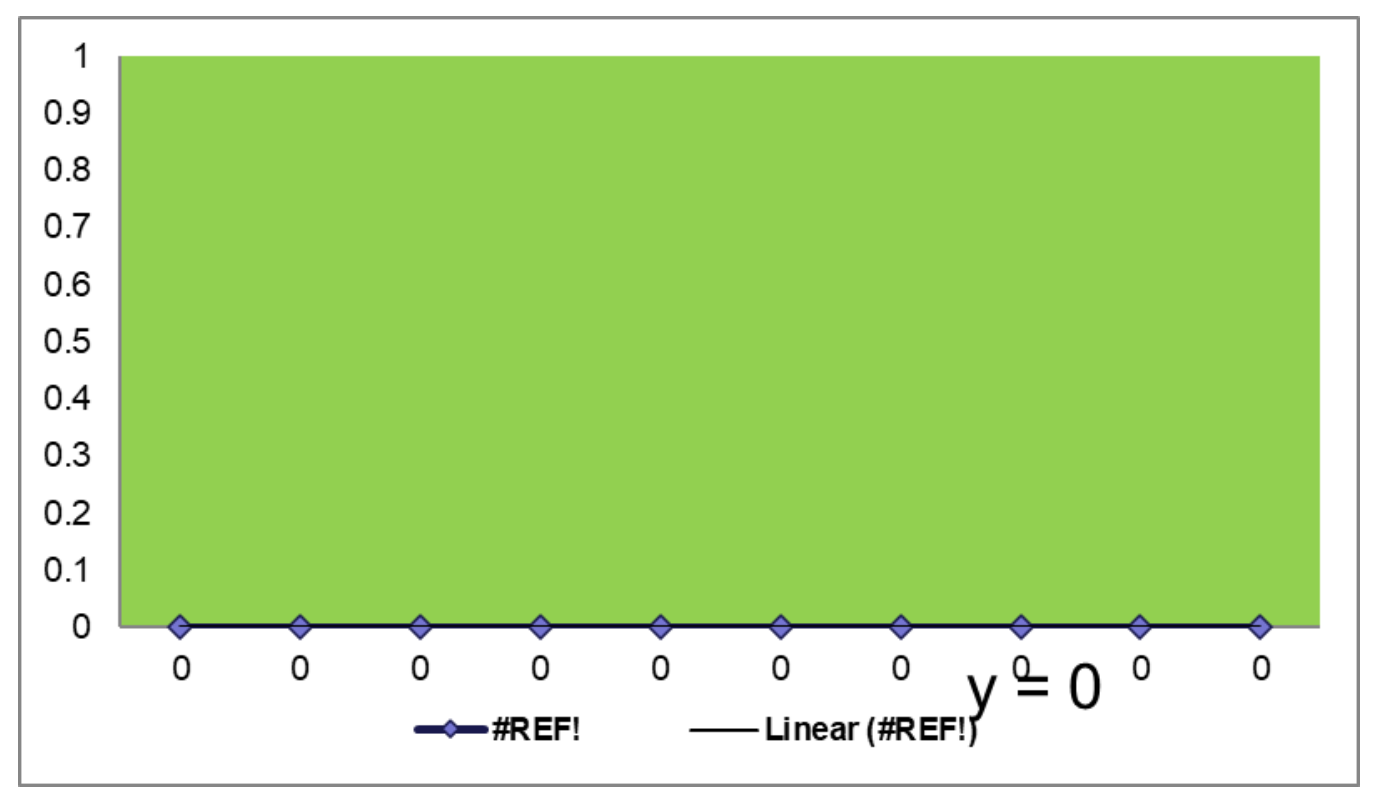

Gambar 5. Perkembangan Jumlah Penduduk SUMUT Tahun 2008-2017

Berdasarkan data tersebut diatas dapat di lihat bahwa Pertumbuhan jumlah penduduk Provinsi Sumatera Utara juga cenderung meningkat dengan laju pertumbuhan rata-rata 1,24 persen per tahun dengan persaman $\mathrm{y}=167,59 \mathrm{x}+12534$. Jumlah penduduk Sumatera Utara paling tinggi terjadi pada tahun 2017 yaitu 14.262.147 jiwa dengan tingkat pertumbuhan 1,24\%. Jumlah penduduk tersebut membutuhkan kedelai sebanyak 96.839,98 ton dimana untuk kebutuhan per kapita sebesar $6.79 \mathrm{Kg}$ pertahun. Jumlah penduduk Sumatera utara yang paling rendah terjadi pada Tahun 2008 dengan jumlah penduduk sebanyak 12.569.196 jiwa dan membutuhkan kedelai sebanyak $37.958,97$ ton dimana jumlah yang dibutuhkan perkapita 3,02 kg/tahun.

Akibat tingkat pertumbuhan yang besar terutama tingkat kelahiran yang tidak dapat ditekan maka akan terjadi komposisi penduduk usia muda menjadi lebih besar, sehingga mengkwatirkan terjadinya ledakan penduduk dimasa yang akan datang. Hal ini akan berakibat pada tingginya kebutuhan akan pangan konsumsi kedelai dimana untuk Tahun 2008 dibutuhkan sebanyak 74.258,2 ton dan terus naik pada Tahun 2017 menjadi sebanyak 136.418 Ton, yang digunakan untuk kebutuhan per kapita oleh masyarakat Sumatera Utara mencapai $6,79 \mathrm{Kg} /$ Tahun ditambah Kebutuhan untuk memenuhi kebutuhan ajan pakan ternak 0,34 persen, tercecer 5 persen dari hasil produksi, benih 50 $\mathrm{kg} /$ Ha untuk 1 (satu) kali penanaman, kebutuhan industri sebanyak 2,76/kapita/tahun. Peningkatan produksi dan ketersediaan kedelai yang berbasis produksi lokal mutlak dipacu untuk mengejar laju peningkatan kebutuhan penduduk yang tumbuh dengan pesat dan lebih tinggi dari pertumbuhan produksi dan ketersediaan.

\section{Analisis Perkembangan jumlah konsumsi perkapita pertahun terhadap kebutuhan} Kedelai di Provinsi Sumatera Utara tahun 2008 - 2017

Perkembangan Jumlah konsumsi perkapita pertahun selama kurun waktu 10 (sepuluh) tahun terakhir mulai tahun 2008-2017 di Provinsi Sumatera Utara .Konsumsi merupakan salah satu bagian dari kebutuhan pokok manusia yang dapat diperoleh dengan mengalokasikan seluruh pendapatannya untuk dimanfaatkan dalam membeli seluruh kebutuhannya, sehingga setiap manusia selalu berusaha mengoptimalkan alatalat pemuas kebutuhan dengan pengorbanan sekecil-kecilnya mengharapkan hasil yang semaksimal mungkin. Untuk menyikapi hal tersebut maka konsumsi yang dimaksud adalah terkait dengan konsumsi kedelai sebagai kebutuhan pokok ketiga setelah padi 
dan jagung oleh setiap penduduk sehingga dapat menjamin seseorang dapat menciptakan manfaat lebih lanjut dalam perolehan tingkat pendapatan yang cukup memadai bagi keluarganya nanti setelah mengkonsumsi kedelai tersebut. Sebagaimana diketahui bahwa mengkonsumsi kedelai dapat mempertinggi kemampuan seseorang dalam menciptakan berbagai akses karena kedelai dapat menghasilkan kalori yang dapat memberikan semangat hidup sehingga dapat bekerja dengan sekuat tenaganya dalam menggapai usaha peningkatan pendapatan bagi keluarganya melalui kegiatan ekonomi yang dijalankan setiap hari oleh setiap rumah tangga.

Jumlah konsumsi kedelai per kapita pertahun di Sumatera Utara dari tahun 2008 untuk kebutuhan rumah tangga sebesar 3,02 Kg sebanyak 37.958,97 Ton, dan pada tahun 2017 naik menjadi 6,79 Kg sebanyak 96.839,98 Ton. Seluruh kebutuhan terhadap kedelai di olah menjadi Tempe \& tahu $(83,7 \%)$, Kecap \& tauco $(14,7 \%)$, Benih, pakan, olahan lainnya $(1,6 \%)$.

\section{Perkembangan jumlah Ketersediaan terhadap kebutuhan Kedelai di Provinsi} Sumatera Utara tahun 2008 - 2017

Perkembangan Jumlah ketersedian kedelai selama kurun waktu 10 (sepuluh) tahun terakhir mulai tahun 2008-2017 di Provinsi Sumatera Utara dapat dilihat pada tabel berikut.

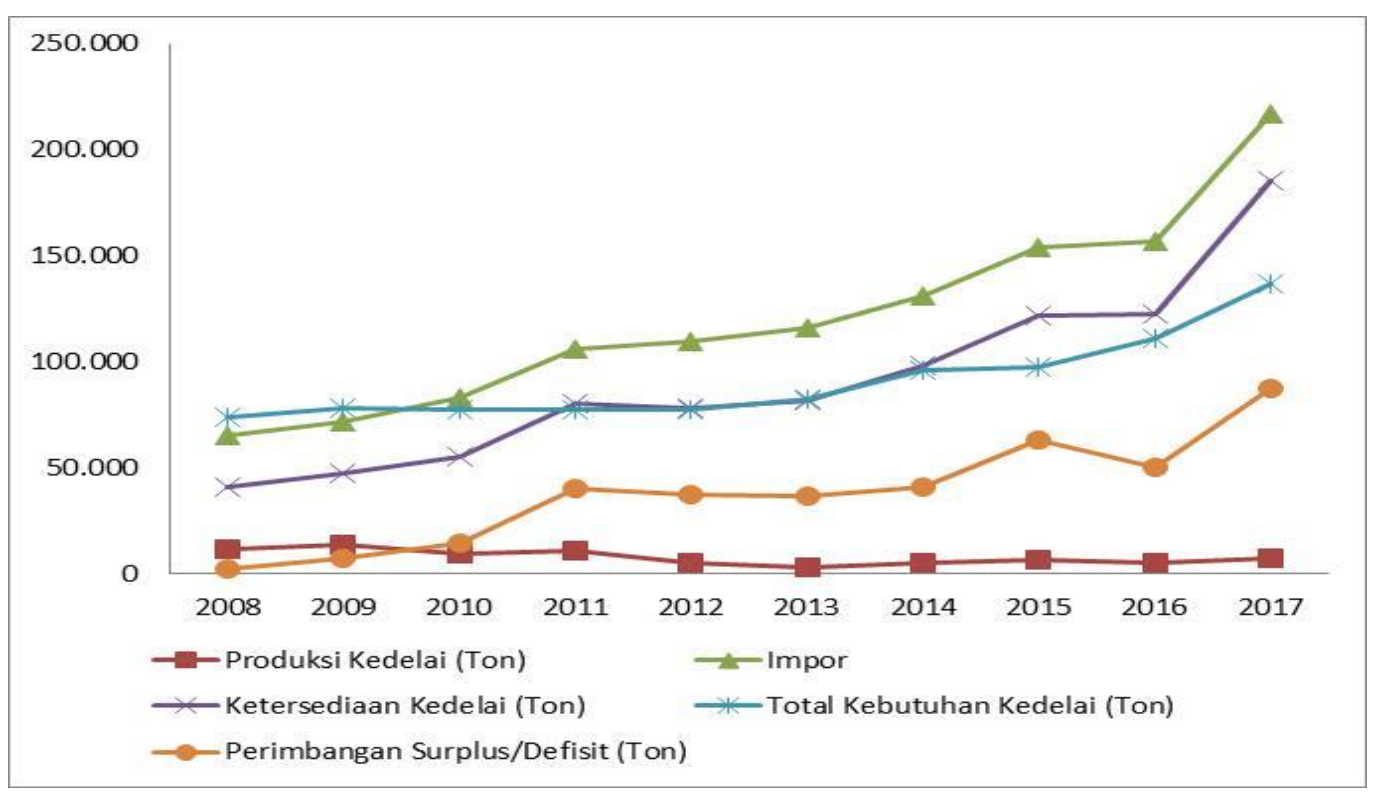

Gambar 6. Ketersediaan terhadap kebutuhan Kedelai di Propinsi

Berdasarkan analisis data diketahui bahwa Kebutuhan Kedelai di Provinsi Sumatera Utara dipenuhi dari peningkatan impor sehingga menghasilkan surplus pada tahun 2017 sebesar 87.790 ton. Surplus yang terjadi digunakan untuk memenuhi kebutuhan propinsi lain seperti Padang dan Aceh. Surplus juga digunakan sebagai bahan pakan ternak pengganti jagung karena larangan impor jagung untuk pakan ternak pada Tahun 2015. Hal ini di ketahui dari data pengimpor kedelai yaitu perusahaan importir pakan ternak.

Berdasarkan data jumlah ketersediaan kedelai, data impor, dan jumlah penduduk di Sumatera Utara periode 2008-2017 dapat diketahui bahwa kondisi ketahanan pangan komoditi kedelai di Sumatara Utara cukup tersedia, tetapi hal ini sangat mengkhawatirkan dari segi ketahanan pangan. Jumlah impor yang tinggi merupakan 
salah satu faktor penting sehingga kedelai tersedia di Sumatera Utara. Hal ini menunjukkan bahwa terjadi ketergantungan bahan pangan kedelai impor. Oleh karena itu pemerintah wajib melakukan upaya khusus agar ketergantungan terhadap impor segera diakhiri. Pemerintah perlu melakukan upaya khususnya untuk dapat meningkatkan produksi oleh petani lokal dengan cara membuat harga eceran terendah (HET) dan menyiapkan pemasaran yang baik dengan cara menyiapkan satu lembaga untuk menampung kedelai hasil produksi petani.

\section{SIMPULAN}

Rata-rata pertumbuhan produksi kedelai di Provinsi Sumatera Utara selama 10 tahun terakhir mengalami kenaikan sebesar 4,09 \% per tahunnya. Rata-rata produktivitas kedelai di Provinsi Sumatera Utara selama 10 tahun terakhir sebesar 1,16 ton/ha. Produksi kedelai di Provinsi Sumatera Utara setiap tahunnya tidak mampu memenuhi kebutuhannya. Ketersediaan kedelai di Provinsi Sumatera Utara dipenuhi dengan cara impor.

\section{DAFTAR PUSTAKA}

Adnindita. K. 2013. Ketersediaan Kedele di Indonesia [Skripsi]. Yogyakarta: Fakultas Pertanian Universitas Gadjah Mada.

Arifin, Bustanul, 2007. Diagnosis Ekonom Politik Pangan dan Pertanian. Jakarta: Rajawali Press.

Andi Facino. 2012. Penawaran Kedele Dunia dan Permintaan Impor Kedele Indonesia Serta Kebijakan Perkedelean Nasional . Bogor: Fakultas Ekonomi dan Manajemen, Institut Pertanian Bogor.

Anggasari P. 2008. Analisis faktor-faktor yang Mempengaruhi Volume Impor Kedele Indonesia. Bogor: Fakultas Ekonomi dan Manajemen, Institut Pertanian Bogor.

Badan Pusat Statistik. 2004. Statistik Indonesia : Statistical Year Book of Indonesia, hal 465. Jakarta : BPS.

BPS. Badan Pusat Statistik. 2001. Statistik Indonesia : Statistical Year Book of Indonesia, hal 483. Jakarta : BPS.

Badan Pusat Statistik. 1997. Statistik Indonesia : Statistical Year Book of Indonesia, hal 487. Jakarta :

BPS.2013.http://sirusa.bps.go.id/index.php?r=publikasi/search\&key=impor+ kedele / diakses 18 maret 2013

Boediono, 2000, Teori Pertumbuhan Ekonomi. BPFE, Yogyakarta.

BPS] Badan Pusat Statistik. 1993-2012. "Produksi, Prodiktivitas dan Luas Lahan Kedele Indonesia”. Jakarta: Badan Pusat Statistik. D.K. Swastika dan Sudaryanto, T. 2007. "Ekonomi Kedele di Indonesia”. Hlm 127.

Sumarno, Suyamto, A. Widjono, Hermanto, dan H. Kasim (Ed.). Kedele Teknik Produksi dan Pengembangan Tanaman Pangan, Bogor. Diakses tanggal 13 Maret 2014

Direktorat Jenderal Tanaman Pangan. 2004. "Profil Kedele". Ed ke-1. Direktorat Kacangkacangan dan Umbiumbian, Kementrian Pertanian, Jakarta. Dominick Salvatore, International Economics, Fifth Edition, Prentice-Hall, Inc, A Simon \& Schuster Company Englewood Clifs, New Jersey, 2006. FAOSTAT. 2005. "Statistical Data of Food Balance Sheet". www.fao.org. [accessed on 23 March, 2013]. FAO. 2014. "Statistical Data of Food Balance Sheet". http://w ww.foodsecurityportal.org/api/countries/fao-production-soybean diakses 12 maret $201411.02 \mathrm{am}$

D.K. Swastika dan Sudaryanto, T. 2007. "Ekonomi Kedele di Indonesia”. Hlm 1-27. Dalam Sumarno, Suyamto, A. Widjono, Hermanto, dan H. Kasim (Ed.). Kedele Teknik Produksi dan Pengembangan Tanaman Pangan, Bogor. Diakses tanggal 21 Oktober 2018

Direktorat Jenderal Tanaman Pangan. 2004. "Profil Kedele". Ed ke-1. Direktorat Kacangkacangan dan Umbiumbian, Kementrian Pertanian, Jakarta

Dominick Salvatore, International Economics, Fifth Edition, Prentice-Hall, Inc, A Simon \& Schuster Company Englewood Clifs, New Jersey, 2006.

Ginting, E., S. S. Antarlina, dan S. Widowati. 2009. "Varietas unggul kedele untuk bahan baku industri pangan". Jurnal Litbang Pertanian

Irawan, A. 2013. Seriuskah Swasembada Kedele. Koran. Tempo.co/.../seriuskah-swasembada-kedele, 
Nanang. 2012. Buffer stock kedele diperlukan. <http://www.kppu.go.id/id/kppu-buffer-stockkedelediperlukan/>. Press Release Resmi Komisi Pengawas Persaingan Usaha. Diakses tanggal 19 Oktober 2018

Purwanto T. 2009. Analisis Faktor-faktor yang Mempengaruhi Impor Kacang Kedele Nasional Periode 1987-2007 [Skripsi]. Bogor: Fakultas Ekonomi dan Manajemen, Institut Pertanian Bogor.

Purnamasari R. 2006. Analisis Faktor-faktor Yang Mempengaruhi Produksi dan Impor Kedele di Indonesia [Skripsi]. Bogor: Fakultas Pertanian, Institut Pertanian Bogor

Saragih, B.2001. Pembangunan Pertanian 2001-2004 Departemen Pertanian. Jakarta.

Sukirno Sadono. 1998. Mikro Ekonomi Teori Pengantar Edisi Kedua. PT Raja Grafindo Persada Jakarta.

Sukirno Sadono. 2005. Mikro Ekonomi Teori Pengantar Edisi Ketiga. PT Raja Grafindo Persada Jakarta.

Sumanjaya, Rakhmat, Syahrir Hakim Nasution dan Arifin Hamzah. Ekonomi Internasional, Penerbit USU Press, Medan. 2012: 12-15.

Suprapto, H. 2001. Bertanam Kedele. Jakarta : Penebar Swadaya.

Peraturan Menteri Pertanian No 65 Tahun 2010. Tentang Standar Pelayanan Minimal Bidang Ketahanan Pangan Provinsi dan Kabupaten/Kota

Badan Perencanaan Pembangunan Daerah Provinsi Sumatera Utara, 2008. Peraturan Daerah Provinsi Sumatera Utara tentang Rencana Pembangunan Jangka Panjang Daerah (RPJPD) Provinsi Sumatera Utara Tahun 2005-2025. Badan Perencanaan Pembangunan Daerah Provinsi Sumatera Utara, Medan.

Badan Pusat Statistik Provinsi Sumatera Utara, 2012. Sumatera Utara Dalam Angka. Badan Pusat Statisik Provinsi Sumatera Utara. Katalog BPS : 1102001.12. 